\title{
Prospective of Local Cereal and Pulses for Free Gluten Toast in Egypt
}

\author{
Kadria M. El Sayed ${ }^{1}$, M. Abd El-Sattar Ahmed ${ }^{*}$, A. Salah Abu Donkol², and M. H. Younes \\ ${ }^{1}$ Professor of crop science, Alexandria University. \\ ${ }^{2}$ Chairman of Slah Abu Donkol Companies. \\ 3 Post graduate student. \\ *Corresponding auther (mohamed.a@alexu.edu.eg)
}

\begin{abstract}
The main objective of the recent study was producing gluten-free toast using local grains and legumes, i.e.; rice, sorghum and chic-pea. Broken rice grains, sorghum and chic-pea were obtained from the local market. The experiments were carried out in The Arabian Company for Milling and Food Industries (one of Salah Abu Donkol Companies). Six blends along with pure rice and sorghum flours were used. Two wheat flour standards (Austrian and Russian) were included for product characters comparison higher levels of sorghum flour $(60 \%)$ in blends, gave a negative effect on freegluten toast color properties (L, a and b). Increasing the level of chic-pea flour in blends from 10 to $15 \%$ or from 15 to $20 \%$, gave a negative effect on toast whiteness and yellowness, along with a positive improvement in toast reddishment. Increasing rice or sorghum percentage in the studied blends from 30 to $60 \%$ gave a negative effect on toast volume. Meanwhile, increasing chic-pea levels from 10 to 15 to 20 percent, gave a positive effects on toast volume. Commonly, free-gluten toast made from rice flour showed the least crude fiber content. Ascending proportion of chic-pea flour in sorghum and rice flour blends, improved crude fiber percentage in produced toast, sensory evaluation of free-gluten toast was disliked in blends with $60 \%$ rice flour $v s$. those of $30 \%$ rice flour. While, blends with $60 \%$ sorghum flour, were most liked over those with $30 \%$ sorghum flour. Also, sensory evaluation of free-gluten toast was reduced as the contribution of chic-pea flour to blend was ascending as 10,15 and $20 \%$. Stalling of toast expressed by peak force required to shear was ascending with the progress of storage. 100\% rice toast expressed the least required peak force in day one and the maximum required peak force in fifth day. Overall storage days, the least stalled toast resulted from $60 \%$ rice $+20 \%$ sorghum $+20 \%$ chic-pea blend followed by $60 \%$ sorghum $+20 \%$ rice $+20 \%$ chic-pea blend, then $60 \%$ sorghum $+25 \%$ rice $+15 \%$ chic-pea blend.
\end{abstract}

Key Words: Free gluten, cereals, pulses, chic-pea, lentil, toast, sensory evaluation, nutritional analysis, shelf-life.

\section{INTRODUCTION}

A gluten-free product is made from a blend of a few (or many) individual gluten-free flours, carefully selected for unique properties they bring, which when used together will work as needed for the bake to be successful. In Egypt, we hope that a "coeliac patient", go to the supermarket and grab that pre-mixed bag of "gluten-free flour" or baked product from the shelf to answer his/her prayer. Rice "Oryza sativa" is the second major cereal crop in Egypt after wheat, with a total product quantity of 5.72 million tons (Year Book of Agricultural Statistics, 2018). Processing of rice, result in an amount of 500.000 tons of broken grains annually. Rice flour made from broken grains in characterized by gluten free and high content of amylase, protein and low molecular weight sugar. Also, sorghum "Sorghum bicolor" is an obligative cereal to upper Egypt, where, high temperature and low atmospheric humidity proliferates grain yield. A total of one million ton of sorghum grains is produced annually (Year Book of Agricultural Statistics, 2018). Beside, the two gluten-free cereals that are available in Egypt, two pulses namely lentils "Lens esculentum" and chic-pea "Cicer arietinum" represents winter legumes for high lands of Upper Egypt.

Up to now, the only available treatment for "celiac" disease in the use of gluten-free diets (Arendt et al., 2011), which, can reverse the damage of intestine (Green and Collier, 2007). Although, there is a wide range of flours that are gluten-free, the final production exhibited bad organoleptic properties, like, hard crust, bad taste and smell, along with high glycemic responses (Berti et al., 2004). Also, such gluten-free products are of low nutritional quality (Gallagher, 2004; and Hager et al., 2011).

During the last times, extensive studies had been made on producing gluten-free products. The production of free-gluten bread is similar to other types of bread. Commonly, details of steps in gluten free bread production are completely different regarding the complication of required additive, and the quantity of required water. Where, required water reach 85 to $125 \%$ of the corresponding required quantity in gluten rich bread (Arendt et al., 2008). Consequently, the behavior and appearance of dough is similar to a cake paste, rather than, bread dough. Gluten free products were made of sorghum, varieties of millet, wheat grass, quinoa and amaranth as pseudo-cereals. Different methods 
for producing gluten free products included the following blends; 1) gluten free flours (rice, sorghum, oats, wheat grass, amaranth, quinoa, teef and maize (Hager et al., 2012)., 2) types of starch (rice starch, maize starch, sweet potato starch, cassava starch) wether natural or pre-gelatinized, 3) dairy products (whey) (Gallagher et al., 2004), 4) protein rich products (egg, soya and maize protein), 5) Hydrocolloids and gums (Guar, xanthan) (Gallagher et al., 2004, and Schober et al., 2005), 6) functional additives wether for medical uses (for diabetes or constipations) or quality improvement (enzymes, emulsions and vitamins, and 7) alternative technologies like sourdough and enzymes(Renzettiet al., 2008, Renzettiet al., 2010, and Hager et al., 2012 a).

Despite the considerable efforts addressed in the last few decades to produce gluten-free bread with sensory characteristics analogous to wheat flour products, in reality the products currently present on the market are yet far from what the consumer is looking for. Therefore, there are no raw materials, additives or ingredients (proteins, hydrocolloids and enzymes) that can completely substitute the gluten, but the combination of row materials, ingredients and proper production technologies could promote the production of gluten-free product of good quality.

The main objective of the recent study was to study the use of local cereals and pulse (rice, sorghum and chic-pea) for producing gluten free Toast

\section{MATERIALS AND METHODS}

Rice, sorghum, and chic-peas were obtained from the local market. Grains were grinded by perten 120 lab Hummer mill then sieved on a 250micron sieve to have a suitably fine flours.

Wheat flours $72 \%$ extraction, were produced from Australian wheat grains $\left(\mathrm{W}_{1}\right)$ for toast bread and Russian wheat grains $\left(\mathrm{W}_{2}\right)(11.5 \%)$ for cake and biscuits. Those flours were used for comparisons with the experiment blends. Those flours produced in the mills of the Arabian milling and Food Industries (Abudonkol companies).
Flours were kept in sealed bags until they are used. Two grams. $\mathrm{Kg}^{-1}$ of Arabian gum (commercial) was added to each free-gluten blend to support dough strength.

Three replicates were used for each of the following characters. All experiments were carried out in The Arabian Company for Milling and Food Industries (one of Salah Abu Donkol Companies).

\section{A. Toast bread quality:}

For each studied blend, the following procedure was followed during dough preparation and baking to measure bread parameters. Dough comprising flour ( $1 \mathrm{~kg}$ ) compressed yeast $(20 \mathrm{~g})$, salt $(5 \mathrm{~g})$, sugar $(100 \mathrm{~g})$ and about $(550 \mathrm{ml})$ of tab water (26. C). Flour blend, sugar, salt, and yeast were added in the kneader and stirred for one minute, Then tab water was added and mixed for two minutes at low speed, then the speed was raised and kneaded for 6 to 8 minutes until the dough formation. Dough rested for 5 minutes, cut into pieces of weight ( $275 \mathrm{~g})$, rolled, and put in the toast mold Fermentation. Fermentation was accomplished at a temperature 40. $\mathrm{C}$ and relative humidity of $75 \%$ for one hour and finally, toast backed at $\left(175^{\circ} \mathrm{C}\right)$ for half hour. The following characters were studied;

$\mathrm{a}_{1}$; Toast bread blends Color properties; according to AACC 14-22.01.

$\mathrm{a}_{2}$; Toast bread blends volume; According to AACC 10-05.01.

This guideline gives general information on the rapeseed displacement method of measuring volume. Volume measurements can be performed for breads, cakes and most baked goods. The idea of displacement has been around since a human first sat in a tub of water. Similarly, baked product can be measured using rapeseed instead of water. Most volume apparatuses have some calibration scale (cubic centimeters, cubic inches, etc.) for quantifying the volume of baked products. This allows for independent and unbiased measurement of volume and discrimination between relatively small differences that might not be observed with other methods.

Table 1: List of studied blends that represent different levels of local cereals flours Substitution and pulse flour addition for making free-gluten toast bread, cakes and biscuits.

\begin{tabular}{|c|c|c|c|c|c|}
\hline $\begin{array}{l}\text { Serial } \\
\text { No. }\end{array}$ & Blends & designation & $\begin{array}{c}\text { rice } \\
\text { flour } \%\end{array}$ & $\begin{array}{c}\text { sorghum } \\
\text { flour } \%\end{array}$ & $\begin{array}{l}\text { Chic-pea } \\
\text { flour } \%\end{array}$ \\
\hline 1 & rice flour & $\mathrm{r}$ & 100 & 0 & 0 \\
\hline 2 & sorghum flour & $\mathrm{s}$ & 0 & 100 & 0 \\
\hline 3 & rice, sorghum, chic-pea 1 & $\mathrm{r} / \mathrm{s} / \mathrm{c}_{1}$ & 60 & 30 & 10 \\
\hline 4 & rice, sorghum, chic-pea 2 & $\mathrm{r} / \mathrm{s} / \mathrm{c}_{2}$ & 60 & 25 & 15 \\
\hline 5 & rice, sorghum, chic-pea 3 & $\mathrm{r} / \mathrm{s} / \mathrm{c}_{3}$ & 60 & 20 & 20 \\
\hline 6 & rice, sorghum, chic-pea 4 & $\mathrm{r} / \mathrm{s} / \mathrm{c}_{4}$ & 30 & 60 & 10 \\
\hline 7 & rice, sorghum, chic-pea 5 & $\mathrm{r} / \mathrm{s} / \mathrm{c}_{5}$ & 25 & 60 & 15 \\
\hline 8 & rice, sorghum, chic-pea 6 & $\mathrm{r} / \mathrm{s} / \mathrm{c}_{6}$ & 20 & 60 & 20 \\
\hline
\end{tabular}


a3; Crude protein percentage; according to AACC.46-11.02

$\mathrm{a}_{4}$; Ether extract (Crude Fat in Flour, Bread, and Baked Cereal Products); according to AACC.3010.01

a5; Crud fiber; according to AACC. 32-10.01

$\mathrm{a}_{6}$; Toast Sensory Evaluation AACC.33-50.02

This sensory attributes including taste, smell, crumb color, texture and overall acceptability of the samples were evaluated by twenty trained panelists, using a five point hedonic scale (Tones et al., 1955). The scale ranges from one to five with one representing the least score (dislike extremely) and five highest score (like extremely). Average of scores for each attribute was scored for each replication. Analysis was made over panelists for each replication.

a7; Toast TVT (shelf Life); according to AACC.7409.01

Toast shelf-life was determined by a Texo vol. texture analyzer (TVT), model 6700, Sweden.

The objective of this method was to quantitatively determine the force required to compress a baked toast by a preset distance. The firmness might be taken as a measure of freshness and quality. This method is applicable to research and quality control evaluation of white pan breads. The principle may also be used to study other loaf types and similar products, such as cakes, if sample preparation, indenter size, and load-cell capacities are adjusted appropriately. Measurements of TVT (peak force, height and peak time) were taken in the first, second, third, fourth and fifth day.

\section{RESULTS AND DISCUSSION}

\section{Toast color properties:}

Visual observations do not give a precise or accurate specification of color for many research and quality control purposes. When color must be expressed in terms of precise objective values, photoelectric reflectance colorimeters can be used. In this method a procedure was described for expressing the color with a reflectance colorimeter, in terms of color in the three directions $\left(\mathrm{L}^{*}, \mathrm{a}^{*}\right.$ and $\left.b^{*}\right)$. The color indication were as follows; L) measures color in the range from black $(-100)$ to white $(+100)$. a) scales the color in the range from red $(+)$ to green (-) b) measure color in the range from yellow $(+)$ to blue $(-)$.

Mean squares of gluten-free toast color properties made from the studied blends were presented in Table $r$. Blends gave significantly different $(\mathrm{p} \geq 0.01)$ color properties of toast, indicated by (L) (black to white), (a) (red to green) and (b) (yellow to blue). Also, orthogonal comparisons, showed that color of gluten-free toast made from blends with $60 \%$ rice or sorghum flours, were significantly different $(\mathrm{p} \geq 0.01)$ in color indicators (L, a and b), from those made from blends with $30 \%$ rice or sorghum flours. Meanwhile, blends with $10 \%$ chic-pea flour gave gluten-free toast of significantly $(\mathrm{p} \geq 0.01)$ different color indicators. That result was also true for gluten-free toast made from blends with $15 \%$ chic-pea flour $v s$. blends with $20 \%$ chic-pea flour.

Mean of gluten-free toast color properties as affected by flour blends were illustrated in Table $r$. A gluten rich toast made from $100 \%$ Australian wheat flour was included as a standard check. Gluten-free toast, that was made from rice flour, enriched by Arabic gum, showed the nearest color properties (L, a and b) to the standard check. Whereas, blend of pure sorghum flour and Arabic gum, enjoyed the least significant color properties (dark color). Gluten-free toast that made from blend of $60 \%$ rice $+20 \%$ sorghum $+20 \%$ chic-pea flours exhibited moderate and acceptable color properties. Meanwhile, Blends with $60 \%$ sorghum flour, gave gluten-free toast of dramatically inferior color properties. It was worthy to notice that, color properties of toasts, that were made from any of the studied gluten-free blends were of darker color (low values of $\mathrm{L}$ ), more reddish (high values of a) and pale yellow (low values of $b$ ), relative to the standard gluten-rich check.

Orthogonal comparisons between different levels of rice, sorghum and chic-pea in gluten-free blends on color properties of toast were presented in Table $\varepsilon$. Raising the level of rice flour in gluten-free blend from $30 \%$ to $60 \%$ gave a positive response in all color properties (L, a, and b).

Table 2: Mean squares of gluten-free toast color properties made from the studied flour blends.

\begin{tabular}{lcccc}
\hline \multirow{2}{*}{ S.O.V. } & \multirow{2}{*}{ d.f. } & \multicolumn{3}{c}{ M.S. } \\
\cline { 3 - 5 } & & 8 & $\mathbf{A}$ & $\mathbf{b}$ \\
\hline Blends & 1 & $16.435^{* *}$ & $14.683^{* *}$ & $43.446^{* *}$ \\
\hline 60\% ricevs. 30\% rice & 1 & $4.951^{* *}$ & $7.058^{* *}$ & $32.130^{* *}$ \\
\hline 60\% sorghumvs. 30\% sorghum & 1 & $2.845^{* *}$ & $11.133^{* *}$ & $18.233^{* *}$ \\
\hline 10\% chic-peavs. 15\% chic-pea & 1 & $0.099^{* *}$ & $0.154^{* *}$ & $0.649^{* *}$ \\
\hline 15\%chic-peavs.20\% chic-pea & 16 & $0.092^{*}$ & $0.154^{* *}$ & $0.658^{* *}$ \\
\hline Error & & 0.011 & 0.002 & 0.001 \\
\hline
\end{tabular}


Table 3: Means of gluten-free toast color properties as affected by the studied flour blends.

\begin{tabular}{|c|c|c|c|c|}
\hline \multirow[b]{2}{*}{ Blends } & \multirow[b]{2}{*}{ Designation } & \multicolumn{3}{|c|}{ Means } \\
\hline & & $\begin{array}{c}\mathbf{L} \\
(\lambda)\end{array}$ & $\begin{array}{c}\mathbf{a} \\
(\lambda)\end{array}$ & $\begin{array}{c}\mathbf{b} \\
(\lambda)\end{array}$ \\
\hline $100 \%$ Rice & $\mathrm{r}$ & $46.43_{\mathrm{a}}$ & $8.63_{\mathrm{a}}$ & $12.76_{a}$ \\
\hline $100 \%$ Sorghum & $\mathrm{s}$ & $42.42_{\mathrm{f}}$ & $2.48_{\mathrm{g}}$ & $2.56_{h}$ \\
\hline $60 \%$ rice, $30 \%$ sorghum, $10 \%$ chic-pea 1 & $\mathrm{r} / \mathrm{s} / \mathrm{c}_{1}$ & $45.38_{\mathrm{d}}$ & $6.02_{\mathrm{b}}$ & $10.12_{d}$ \\
\hline $60 \%$ rice, $25 \%$ sorghum, $15 \%$ chic-pea 2 & $\mathrm{r} / \mathrm{s} / \mathrm{c}_{2}$ & $45.67_{\mathrm{c}}$ & $5.95_{\mathrm{c}}$ & $10.84_{c}$ \\
\hline $60 \%$ rice, $20 \%$ sorghum, $20 \%$ chic-pea 3 & $\mathrm{r} / \mathrm{s} / \mathrm{c}_{3}$ & $45.94_{b}$ & $5.87_{\mathrm{c}}$ & $11.57_{\mathrm{b}}$ \\
\hline $30 \%$ rice, $60 \%$ sorghum, $10 \%$ chic-pea 4 & $\mathrm{r} / \mathrm{s} / \mathrm{c}_{4}$ & $44.18_{\mathrm{e}}$ & $4.18_{\mathrm{d}}$ & $7.06_{\mathrm{g}}$ \\
\hline $25 \%$ rice, $60 \%$ sorghum, $15 \%$ chic-pea 5 & $\mathrm{r} / \mathrm{s} / \mathrm{c}_{5}$ & $44.26_{\mathrm{e}}$ & $3.80_{\mathrm{e}}$ & $7.27_{\mathrm{f}}$ \\
\hline $20 \%$ rice, $60 \%$ sorghum, $20 \%$ chic-pea 6 & $\mathrm{r} / \mathrm{s} / \mathrm{c}_{6}$ & $44.34_{\mathrm{e}}$ & $3.42_{\mathrm{f}}$ & $7.48_{\mathrm{c}}$ \\
\hline \multicolumn{5}{|l|}{ Standard check } \\
\hline $100 \%$ Australian wheat flour & $\mathrm{W}_{1}$ & 50.85 & 1.33 & 15.47 \\
\hline L.S.D. 0.01 & & 0.250 & 0.107 & 0.075 \\
\hline
\end{tabular}

Table 4: Orthogonal comparisons between different levels of rice, sorghum and chic-pea in gluten-free blends on color properties of toast.

\begin{tabular}{lcccccc}
\hline \multirow{2}{*}{ Comparison } & \multicolumn{3}{c}{ Effect } & \multicolumn{3}{c}{ Significance } \\
\cline { 2 - 7 } & $\mathbf{L}$ & $\mathbf{a}$ & $\mathbf{b}$ & $\mathbf{L}$ & $\mathbf{a}$ & $\mathbf{b}$ \\
$(\boldsymbol{\lambda})$ & $(\lambda)$ & $(\lambda)$ & $(\lambda)$ & 0.000 & 0.000 & 0.000 \\
\hline 60\% rice $v s .30 \%$ rice & 0.371 & 0.443 & 0.945 & 0.000 & 0.000 \\
\hline 60\% sorghum $v s$. 30\% sorghum & -0.281 & -0.556 & -0.712 & 0.000 & 0.000 & 0.000 \\
\hline 10\% chic-pea $v s .15 \%$ chic-pea & -0.091 & 0.113 & -0.233 & 0.008 & 0.000 & 0.000 \\
\hline 15\% chic-pea $v s$. 20\% chic-pea & -0.088 & 0.113 & -0.234 & 0.011 & 0.000 & 0.000 \\
\hline
\end{tabular}

L: white color a: red color b: yellow color

Those responses were highly significant $(\mathrm{p} \geq 0.001)$. Meanwhile, higher levels of sorghum flour $(60 \%)$ in blends, gave a negative effect on gluten-free toast color properties (L, a and b). Those responses were also significant $(\mathrm{p} \geq 0.001)$. Increasing the level of chic-pea flour in blends from 10 to $15 \%$ or from 15 to $20 \%$, gave a negative effect on toast whiteness and yellowness, along with a positive improvement in toast reddishness.

Commonly, it might be concluded that rice flour improves the overall color properties of gluten-free toast. While, high levels of sorghum flour leads to darker color of gluten-free toast. Meanwhile, increasing the level of chic-pea flour in gluten-free toast reduced toast brightness and increased reddishness.

Color properties were improved by the replacement with legumes flour (Eissa et al., 2007). Also, Gomez et al., (2008) indicated a difference in color with legume inclusion. While, Islam et al., (2011), recorded an improvement in bread color with brown rice flour in blend. On the other hand, Mohammed et al., (2012) reached that chic-pea flour substitution, gave a strongly brown unacceptable color to consumer.

\section{Toast volume:}

Toast volume was measured using rape seed displacement. This might allow for independent and unbiased measurement and discrimination between relatively small differences that might not be observed with other methods.

Mean square of gluten-free toast volume as affected by different studied blends was shown in Table $\bullet$. Toast volume was significantly $(\mathrm{p} \geq 0.01)$ affected by the used flour blend. Orthogonal comparison between blends of $60 \%$ and $30 \%$ rice flour was significant ( $\mathrm{p} \geq 0.01)$.

Table 5: Mean squares of gluten-free toast volume as affected by different studied blends.

\begin{tabular}{lcc}
\hline S.O.V. & d.f. & Volume \\
\hline Blends & 8 & $54217^{* *}$ \\
\hline $60 \%$ rice $v s .30 \%$ rice & 1 & $23256.250^{* *}$ \\
\hline $60 \%$ sorghum. $v s . \%$ sorghum & 1 & $21121.778^{* *}$ \\
\hline $10 \%$ chic-pea. $v s .15 \%$ chic-pea & 1 & $16.333^{*}$ \\
\hline $15 \%$ chic-pea. $v s .20 \%$ chic-pea & 1 & $18.750^{*}$ \\
\hline Error & 16 & 4.314 \\
\hline
\end{tabular}


Also, toast volume of blends with $60 \%$ vs.30\% sorghum significantly $(\mathrm{p} \geq 0.01)$ varied. Blends with $10 \%, 15 \%$ or $20 \%$ chic-pea flour, significantly ( $\mathrm{p} \geq 0.05$ ) affected free gluten toast volume.

Means of gluten-free toast volume $\left(\mathrm{cm}^{3}\right)$ among the studied blends were presented in Table $?$. Gluten-free toast of the studied blends cleared that the highest significant loaf volume resulted from $100 \%$ sorghum flour $\left(600.0 \mathrm{~cm}^{3}\right)$. Whereas, the least significant toast volume was presented by $100 \%$ rice flour $\left(295.0 \mathrm{~cm}^{3}\right)$. The second rank of toast volume $\left(499.0 \mathrm{~cm}^{3}\right)$ resulted from $60 \%$ sorghum $+20 \%$ chic-pea flour blends. Toast volume of $494.0 \mathrm{~cm}^{2}$, resulted with $60 \%$ sorghum $+25 \%$ rice $+15 \%$ chicpea blend, occupied the third rank. The fourth toast volume rank $\left(488.7 \mathrm{~cm}^{3}\right)$, was presented by loaves made from $60 \%$ sorghum $+30 \%$ rice $+10 \%$ chicpea.

Commonly, toast of large volume resulted from $100 \%$ sorghum flour, followed by $60 \%$ sorghum + $20 \%$ rice $+20 \%$ chic-pea blend, While, the least free gluten volume resulted from $100 \%$ rice flour. It was valuable to notice that, blends with higher rice flour percentage, exhibited lower volume. Also, substitution of sorghum flour by chic-pea flour in $60 \%$ rice flour blends gave substantial reduction in toast volume $\left(397.0,387.0\right.$ and $377.0 \mathrm{~cm}^{3}$ for $(60 \%$ rice $+30 \%$ sorghum $+10 \%$ chic-pea $),(60 \%$ rice+ $25 \%$ sorghum $+15 \%$ chic-pea) and $(60 \%$ rice $+20 \%$ sorghum $+20 \%$ chic-pea) blend, respectively.

Orthogonal comparisons, between different levels of rice, sorghum and chic-pea, in gluten-free blends on toast volume were shown in Table $v$. Increasing rice percentage in the studied blends from 30 to $60 \%$ gave a negative effect on toast volume. That effect was significant $(p \geq 0.001)$. While, increasing sorghum levels in blends from 30 to $60 \%$ gave a positive significant effect on toast volume. Meanwhile, increasing chic-pea levels from 10 to 15 to 20 percent, gave a positive effects on toast volume. That effect was not significant with chic-pea rise from 10 to $15 \%$. While, reached the level of significance with increasing chic-pea from 15 to $20 \%$.

Gluten-free bread was characterized by higher volume and softer crumb relative to gluten-rich bread (Arendt et al., 2002). An optimum supplementation of $12.5 \%$ pea flour resulted in the best bread volume (Sadowska et al., 2003). Hooda and Jood (2005), recommended the addition of Fenugreek flour at 5 to $20 \%$, for better bread volume. Lazaridou et al., (2007) postulated that, the addition of xanthan gum improved loaf volume and crumb firmness of gluten-free bread. Also, the addition of xanthan gum, to gluten-free $(100 \%$ rice flour) bread, increased bread volume (Sciarini et al., 2010). Mastromatteo et al., (2012) explained the role of xanthan gum as it interact with water during the bread-making process, producing a gel network that served dough viscosity and strenthed the boundaries of expanding cells. That led to an increased gas retention capability during proofing and baking, consequently improved loaf volume. Rai et al., (2012) obtained an increase in loaf volume with increases of rice-flour in blend. Roberts et al., (2012) recorded an improvement in loaves volume with fenugreek gum inclusion at $10 \%$ of blends. Phimolsiripol et al., (2012) recommended the addition of rice bran to gluten free blends to improve specific volume of bread.

Oppositely, Tanaka (1972) and Islam et al., (2001) postulated that loaf volume was reduced with increasing rice flour percentage in gluten-free blend. Demirkesen et al., (2010) obtained a decline in loaf volume with chestnut flour inclusion (high sugar) in blends. Butt et al., (2011) reached that bread volume decreased with raising the level of low-pea flour in blends. Also, Masttromatteo et al., (2012), cleared that extra raising the level of xanthan gum in blends decreased loaves volume. Mohammed et al., (2012) obtained impairment in loaf volume with chic-pea flour addition over $20 \%$ of the blend.

Table 6: Means of free gluten toast volume $\left(\mathrm{cm}^{3}\right)$ among the studied blends.

\begin{tabular}{|c|c|c|}
\hline Blend & Designation & $\begin{array}{r}\text { Mean } \\
\mathrm{Cm}^{3} \\
\end{array}$ \\
\hline $100 \%$ Rice & $\mathrm{r}$ & $295.000_{\mathrm{h}}$ \\
\hline $100 \%$ Sorghum & $\mathrm{s}$ & $600.000_{\mathrm{a}}$ \\
\hline $60 \%$ rice, $30 \%$ sorghum, $10 \%$ chic-pea 1 & $\mathrm{r} / \mathrm{s} / \mathrm{c}_{1}$ & $397.000_{\mathrm{e}}$ \\
\hline $60 \%$ rice, $25 \%$ sorghum, $15 \%$ chic-pea 2 & $\mathrm{r} / \mathrm{s} / \mathrm{c}_{2}$ & $387.000_{\mathrm{f}}$ \\
\hline $60 \%$ rice, $20 \%$ sorghum, $20 \%$ chic-pea 3 & $\mathrm{r} / \mathrm{s} / \mathrm{c}_{3}$ & $377.000_{\mathrm{g}}$ \\
\hline $60 \%$ rice, $30 \%$ sorghum, $10 \%$ chic-pea 4 & $\mathrm{r} / \mathrm{s} / \mathrm{c}_{4}$ & $488.667_{\mathrm{d}}$ \\
\hline $60 \%$ rice, $25 \%$ sorghum, $15 \%$ chic-pea 5 & $\mathrm{r} / \mathrm{s} / \mathrm{c}_{5}$ & $494.000_{\mathrm{c}}$ \\
\hline $60 \%$ rice, $20 \%$ sorghum, $20 \%$ chic-pea 6 & $\mathrm{r} / \mathrm{s} / \mathrm{c}_{6}$ & $499.000_{\mathrm{b}}$ \\
\hline \multicolumn{3}{|l|}{ Standard check } \\
\hline $100 \%$ Australian wheat flour & $\mathrm{W}_{1}$ & 743.333 \\
\hline L.S.D. 0.01 & 4.95 & \\
\hline
\end{tabular}


Table 7: orthogonal comparisons between different levels of rice, sorghum and chic-pea in free gluten blends on toast volume.

\begin{tabular}{lcc}
\hline Comparison & Effect & Significant \\
\hline $60 \%$ rice $v$ s. $30 \%$ rice & -25.417 & 0.000 \\
\hline $60 \%$ sorghum $v$ s. $30 \%$ sorghum & 24.222 & 0.000 \\
\hline $10 \%$ chic-pea $v$ s. $15 \%$ chic-pea & 1.167 & 0.06 \\
\hline $15 \%$ chic-pea $v$ s. $20 \%$ chic-pea & 1.250 & 0.05 \\
\hline
\end{tabular}

Table 8: Mean squares of nutritional analysis for toast made from the studied free-gluten blends, along with the standard check made from Australian wheat.

\begin{tabular}{|c|c|c|c|c|}
\hline \multirow{2}{*}{ S.O.V. } & \multirow[t]{2}{*}{ d.f. } & \multicolumn{3}{|c|}{ M.S. } \\
\hline & & C.P\% & E.E\% & C.F\% \\
\hline Blends & 8 & $12.025^{* *}$ & $4.281^{* * *}$ & $0.358^{* *}$ \\
\hline $60 \%$ rice $v s .30 \%$ rice & 1 & $1.357^{\text {n.s }}$ & $1.436^{\text {** }}$ & $0.090^{* *}$ \\
\hline $60 \%$ sorghum vs. $30 \%$ sorghum & 1 & $7.775^{\text {n.s }}$ & $2.346^{\text {** }}$ & $0.323^{* *}$ \\
\hline $10 \%$ chic-pea $v s .15 \%$ chic-pea & 1 & $0.880^{* *}$ & $0.010^{\text {** }}$ & $0.024^{* *}$ \\
\hline $15 \%$ chic-pea vs. $20 \%$ chic-pea & 1 & $0.875^{* *}$ & $0.145^{*}$ & $0.023^{\text {** }}$ \\
\hline Error & 16 & 3.710 & 0.038 & 0.001 \\
\hline
\end{tabular}

C.P: Crud protein. $\quad$ E.E: Ether extract. $\quad$ C.F: crud fiber.

**, indicate significance at 0.01 level. n.s.; not significantly different.

\section{Toast nutritional analysis:}

Toasts nutritional analysis was determined via crude protein (CP), ether extract (E.E.) and crude fiber (C.F.). Mean squares of nutritional analysis for toast made from the studied gluten-free blends, along with the standard check made from Australian wheat were presented in Table 8. Gluten-free toast made from different blends was significantly $(\mathrm{p} \geq 0.01)$ different in crude protein, ether extract and crude fiber percentages. Blends, that had $60 \%$ rice flour had significantly similar protein percentage to that made with $30 \%$ rice flour. Meanwhile, freegluten toast significantly ( $\mathrm{p} \geq 0.01)$ showed different ether extract and crude fiber, depending on the percentage of rice flour in blends. The aforementioned result was typically similar to the contribution of sorghum flour on the studied three nutritional analysis elements (CP, E.E. and C.F.). Also, gluten-free toast made from blends with 10 , 15 or $20 \%$ chic-pea flour had significantly different percentages of crude protein, ether extract and crude fiber.

Means of free gluten toast nutritional analysis is (crude protein, ether extract and crude fiber) for the studied blends were presented in Table 9 . Free gluten toast made from any of the studied blends had significantly similar crude protein percentages, (9.18 to $11.68 \%$ ), except for, that made from either $100 \%$ rice or $100 \%$ sorghum flours, which exhibited the least crude protein percentages (6.674 and 7.400 for $100 \%$ rice and $100 \%$ sorghum, respectively). It was valuable to notice that the difference in crude protein percentage between the standard gluten-rich check and the studied gluten-free blends had not reached the level of significance.

As for ether extract (E.E) percentage, toast made from $100 \%$ rice flour had the least significant ether extract percentage (1.283\%). Meanwhile, toast made from $100 \%$ sorghum or $60 \%$ sorghum $+25 \%$ rice $+15 \%$ chic-pea or $60 \%$ sorghum $+20 \%$ rice + $20 \%$ chic-pea, enjoyed the highest ether extract value $(4.767,4.300$ and 4.610 , respectively). Blend that had $60 \%$ sorghum $+30 \%$ rice $+10 \%$ chic-pea flours, occupied the second significant rank of ether extract percentage $(3.993 \%)$. On the other hand, blends that had $60 \%$ rice flour, gave toast of significantly similar ether extract in the third rank (3.087 to $3.280 \%$ ).

Commonly, blends with complete sorghum flour $(100 \%)$ or high contribution of sorghum flour $(60 \%)$ provided the highest ether extract inglutenfree toast. While, blends with complete rice flour $(100 \%)$, or high contribution of rice flour $(60 \%)$, gave toast of lower ether extract percentage. The standard gluten-rich check showed toast of lower ether extract relative to all studied blends, except for, $100 \%$ rice flour.

Regarding crude fiber (C.F) percentage, toast made from $60 \%$ sorghum $+20 \%$ rice $+20 \%$ chicpea blend, enjoyed the highest significant value $(1.290 \%)$. While, $100 \%$ rice flour produced toast with the least significant crude fiber percentage $(0.307 \%)$. The latter was significantly lower than standard gluten-rich check $(0.410 \%)$. Blends with high sorghum flour percentage $(60 \%)$, gave loaves of ascending crude fiber percentage paralle to each decrease in rice flour percentage and an increase in chic-pea flour percentage $(1.067,1.180$ and $1.290 \%$ for the following blends, respectively; $60 \%$ sorghum $+30 \%$ rice $+10 \%$ chic-pea, $60 \%$ sorghum $+25 \%$ rice $+15 \%$ chic-pea and $60 \%$ sorghum $+20 \%$ rice + $20 \%$ chic-pea). 
Table 9: Means of free gluten toast nutritional analysis (crude protein, ether extract and crude fiber) for the studied blends.

\begin{tabular}{|c|c|c|c|c|}
\hline \multirow[b]{2}{*}{ Blends } & \multirow[t]{2}{*}{ Designation } & \multicolumn{3}{|c|}{ Means } \\
\hline & & $\begin{array}{l}\text { C.P } \\
(\%)\end{array}$ & $\begin{array}{l}\text { E.E } \\
(\%)\end{array}$ & $\begin{array}{l}\text { C.F } \\
(\%)\end{array}$ \\
\hline $100 \%$ Rice & $\mathrm{r}$ & $6.674_{b b}$ & $1.283_{\mathrm{d}}$ & $0.307_{\mathrm{f}}$ \\
\hline $100 \%$ Sorghum & $\mathrm{s}$ & $7.400_{\mathrm{a}}$ & $4.767_{\mathrm{a}}$ & $1.203_{\mathrm{b}}$ \\
\hline $60 \%$ rice, $30 \%$ sorghum, $10 \%$ chic-pea $_{1}$ & $\mathrm{r} / \mathrm{s} / \mathrm{c}_{1}$ & $9.180_{\mathrm{a}}$ & $3.280_{\mathrm{c}}$ & $0.800_{\mathrm{de}}$ \\
\hline $60 \%$ rice, $25 \%$ sorghum, $15 \%$ chic-pea 2 & $\mathrm{r} / \mathrm{s} / \mathrm{c}_{2}$ & $9.620_{a}$ & $3.087_{\mathrm{c}}$ & $0.867_{\mathrm{d}}$ \\
\hline $60 \%$ rice, $20 \%$ sorghum, $20 \%$ chic-pea $_{3}$ & $\mathrm{r} / \mathrm{s} / \mathrm{c}_{3}$ & $10.060_{\mathrm{a}}$ & $3.217_{\mathrm{c}}$ & $0.933_{\mathrm{d}}$ \\
\hline $60 \%$ rice, $30 \%$ sorghum, $10 \%$ chic-pea 4 & $\mathrm{r} / \mathrm{s} / \mathrm{c}_{4}$ & $10.397 \mathrm{a}$ & $3.993_{b}$ & $1.067_{\mathrm{c}}$ \\
\hline $60 \%$ rice, $25 \%$ sorghum, $15 \%$ chic-pea 5 & $\mathrm{r} / \mathrm{s} / \mathrm{c}_{5}$ & $11.040_{\mathrm{a}}$ & $4.300_{\mathrm{a}}$ & $1.180_{\mathrm{b}}$ \\
\hline $60 \%$ rice, $20 \%$ sorghum, $20 \%$ chic-pea $_{6}$ & $\mathrm{r} / \mathrm{s} / \mathrm{c}_{6}$ & $11.680_{\mathrm{a}}$ & $4.610_{\mathrm{a}}$ & $1.290_{\mathrm{a}}$ \\
\hline \multicolumn{5}{|l|}{ Standard check } \\
\hline $100 \%$ Australian wheat flour & $\mathrm{W}_{1}$ & 13.073 & 1.883 & 0.410 \\
\hline L.S.D. 0.01 & & 4.59 & 0.47 & 0.075 \\
\hline
\end{tabular}

$\begin{array}{lll}\text { C.P: Crud protein } & \text { E. E: Ether extract } & \text { C.F: crud fiber }\end{array}$

Commonly, gluten-free toast made from rice flour showed the least crude fiber content. Ascending proportion of chic-pea flour in sorghum and rice flour blends, improved crude fiber percentage in produced toast. That improvement failed to reach the level of significant in high rice flour $(60 \%)$ blends, But, reached the level of significant in high sorghum flour $(60 \%)$ blends.

To clarify the role of each component in the studied blends to the nutritional analysis of produced toast, orthogonal comparisons were made (Table 1•). Orthogonal comparison between blends with $60 \%$ rice flour $v s$. blends with $30 \%$ rice flour, gave a negative effect on all nutritional analysis elements, i.e.; crude protein, ether extract and crude fiber percentages. Those effects were only significant for ether extract and crude fiber $\%$. Meanwhile, increasing sorghum flour contribution from $30 \%$ to $60 \%$ gave a positive responses in toast nutritional elements, although were significant in case of ether extract and crude fiber percentages. Meanwhile, increasing chic-pea flour in blends from 10 to $15 \%$ gave positive significant responses in nutritional analysis elements of toast. That trend was true when chic-pea flour increased from 15 to $20 \%$ with insignificant response in crude protein percentage to toast.

The obtained results might be discussed through the following review. Balance among essential amino acids might be reached through using a combination of cereal and legume proteins (livingstone et al., 1993). Pulse crops are important source of proteins, carbohydrates, fiber, vitamins and minerals (Perez-Hidalgo et al., 1997). Legume flours also presented higher protein content and different amino acid composition which affect bread characteristics. Increasing levels of pigeon peas flour in the blends significantly increased the protein and mineral content of baked products, which could be utilized to improve the nutritional status of gluten-free products (Harinder et al., 1999). Sotomayor et al., 1999, concluded that, lentil seed provide an excellent source of dietary fiber and complex carbohydrates. Hooda and Jood (2005) reached that, fenugreek flour at 5 to 20 percent levels, increased the protein, minerals (ash) and fiber content of bread. Olaoye et al., (2006), reached that, crude protein, crude fiber, ether extract and ash content of bread, increase proportionally to the level of added soybean flour to the blend, while, the carbohydrate content was observed to decrease. Legume flour enrich the blend regarding manganese, zinc (Maninder et al., 2007), and calcium (Rysova et al., 2010). Butt et al., 2011, obtained an increase in protein fiber, fat and ash content with increasing cowpea flour level from 5 to $20 \%$ of the blend. Islam et al., (2011), gained an increase in protein content by adding brown rice flour to the blend. Hager et al., (2012) stated that rice flour presents technological limitations in bread making due to the poor functional properties of its protein. Hemeda and Mohamed (2012), concluded that legumes flour addition, served as nutritional benefit beside having therapeutic, medical properties. Kadam et al., (2012), concluded the use of legumes as protein enriching agent in baked products, onainly in the form of flours. Mohammed et al., (2012) stated that legumes are among the most important sources of proteins, starch, and dietary fiber, since, those crops contain $18.5-30 \%$ of protein, $32-52 \%$ of starch and $14.6-26.3 \%$ dietry fiber on dry basis. Zlaticakohajdova et al.,(2012), stated that, legumes are inexpensive source of protein.They reached that, lentils flour is a potential supplement to improve chemical and functional properties of produced products. 
Table 10: Orthogonal comparisons between different levels of rice, sorghum and chic-peain free gluten blends on nutritional analysis of gluten-free toast.

\begin{tabular}{lcccccc}
\hline \multirow{2}{*}{ Comparison } & \multicolumn{3}{c}{ Effect } & \multicolumn{3}{c}{ Significance } \\
\cline { 2 - 7 } & $\begin{array}{c}\text { C.P } \\
(\boldsymbol{\%})\end{array}$ & $\begin{array}{l}\text { E.E } \\
(\boldsymbol{\%})\end{array}$ & $\begin{array}{c}\text { C.F } \\
(\boldsymbol{\%})\end{array}$ & $\begin{array}{c}\text { C.P } \\
(\boldsymbol{\%})\end{array}$ & $\begin{array}{c}\text { E.E } \\
(\boldsymbol{\%})\end{array}$ & $\begin{array}{c}\text { C.F } \\
(\boldsymbol{\%})\end{array}$ \\
\hline $60 \%$ ricevs. 30\% rice & -0.194 & -0.200 & -0.050 & 0.366 & 0.000 & 0.000 \\
\hline $60 \%$ sorghumvs. 30\% sorghum & 0.465 & 0.255 & 0.095 & 0.167 & 0.000 & 0.000 \\
\hline $10 \%$ chic-peavs. 15\% chic-pea & -0.271 & -0.028 & -0.045 & 0.000 & 0.000 & 0.000 \\
\hline $15 \%$ chic-peavs. 20\% chic-pea & -0.270 & -0.110 & -0.044 & 0.236 & 0.067 & 0.000 \\
\hline
\end{tabular}

Bhatt and Gupta, (2015), recommended the use of chic-pea flour with sorghum flour to improve nutritional and functional properties of bread. Lalit and Kochhar (2017), recommended the incorporation of fenugreek flour at 5 percent to increase protein and fiber of the blend.

\section{Sensory evaluation:}

Sensory evaluation attributes included; taste, smell, crumb color, texture and overall acceptability. Mean squares of sensory evaluation attributes were presented in Table 1'. Toast made from the different studied gluten-free blends, significantly $(\mathrm{p} \geq 0.01)$ exhibited different sensory evaluation characters (taste, smell, crumb color, texture and overall acceptability). Also, toast made from blends with $60 \%$ rice flour showed significantly different sensory characters than toast made from blends with $30 \%$ rice flour. The same was true with toast made from blends with $60 \% v s$. $30 \%$ sorghum flours. Comparison between blend with $10 \%$ vs. $15 \%$ and $15 \%$ vs. $20 \%$ chic-pea flour reflected on sensory evaluation elements were significant, except for, texture of toast in the latter comparison.

Means of sensory evaluation scores for different sensory attribute and overall acceptability were presented in Table $1 r$. Taste of produced toast were detected as "liked extremely" for blends of $60 \%$ sorghum $+30 \%$ rice flour $+10 \%$ chic-pea flour $(4 / 5), 60 \%$ sorghum $+25 \%$ rice flour $+15 \%$ chic-pea flour $(4 / 5)$ and $60 \%$ sorghum $+30 \%$ rice flour $+20 \%$ chic-pea flour (3.1/5). Whereas, other studied blends gave toast of panelists taste score, significantly similar (from $2.1 / 5$ to $2.9 / 5$ ). It was worth to notice that, toast made from the check wheat flour gained full score by panelists $(5 / 5)$.

Panelists smell score, for toast made from the studied blends, showed that $100 \%$ rice flour and $60 \%$ rice flour $+30 \%$ sorghum flour $+10 \%$ chicpea flour were disliked extremely (2.1/5 and 2.0/5, respectively). Whereas, smells of toast made from the other studied blends were liked extremely $(2.9 / 5$ to $3.5 / 5)$.

Toast crumb color scores for $60 \%$ sorghum + $20 \%$ rice flour $+20 \%$ chic-pea flour was best (3.9/5). Whereas, toast made from blends of $60 \%$ sorghum $+25 \%$ rice flour $+15 \%$ chic-pea flour, $60 \%$ sorghum $+30 \%$ rice flour $+10 \%$ chic-pea flour, $60 \%$ rice flour $+20 \%$ sorghum flour $+20 \%$ chic-pea flour, and $60 \%$ rice flour $+30 \%$ sorghum flour $+10 \%$ chic-pea flour, were significantly and similarly enjoyed the second rank $(3.1 / 5,3.0 / 5$, $3.0 / 5$ and $2.7 / 5$, respectively).

The most liked toast texture were those resulted from $60 \%$ sorghum $+25 \%$ rice $+15 \%$ chic-pea flours and $60 \%$ sorghum $+20 \%$ rice $+20 \%$ chic-pea flours (4.0/5 and 3.9/5, respectively). While, the least liked toast textures were those made from $100 \%$ rice, $60 \%$ rice $+30 \%$ sorghum $+10 \%$ chicpea and $60 \%$ rice $+25 \%$ sorghum $+15 \%$ chicpea(1.6/5, 2.0/5 and 2.0/5, respectively). Blends of $100 \%$ sorghum flour, $60 \%$ rice $+20 \%$ sorghum + $20 \%$ chic-pea, and $60 \%$ sorghum $+30 \%$ rice $+10 \%$ chic-pea occupied a moderate position $(2.8 / 5,2.4 / 5$, and 3.0/5, respectively).

Table 11: Mean squares of sensory evaluation attributes i.e.; taste, smell, crumb color, texture and overall acceptability.

\begin{tabular}{lcccccc}
\hline S.O.V. & d.f. & Taste & Smell & $\begin{array}{c}\text { Crumb } \\
\text { color }\end{array}$ & Texture & $\begin{array}{c}\text { overall } \\
\text { acceptability }\end{array}$ \\
\hline Blends & 8 & $9.211^{* *}$ & $7.550^{* *}$ & $9.250^{* *}$ & $12.7^{* *}$ & $141.094^{* *}$ \\
\hline $60 \%$ rice $v s .30 \%$ rice & 1 & $1.633^{*}$ & $0.833^{* *}$ & $1.408^{* *}$ & $5.633^{* *}$ & $31.008^{* *}$ \\
\hline $60 \%$ sorghum $v s .30 \%$ sorghum & 1 & $19.200^{* *}$ & $10.800^{* *}$ & $3.008^{* *}$ & $20.008^{* *}$ & $200.208^{* *}$ \\
\hline $10 \%$ chic-pea $v s .15 \%$ chic-pea & 1 & $7.225^{* *}$ & $3.025^{* *}$ & $0.900^{* *}$ & $2.500^{* *}$ & $28.900^{* *}$ \\
\hline $15 \%$ chic-pea $v s .20 \%$ chic-pea & 1 & $0.000^{* *}$ & $0.400^{*}$ & $8.100^{* *}$ & $0.225^{\text {n.s }}$ & $16.900^{* *}$ \\
\hline Error & 16 & 0.162 & 0.062 & 0.068 & 0.117 & 0.394 \\
\hline
\end{tabular}


Table 12: Means of sensory evaluation scores for different sensory attribute and overall acceptability.

\begin{tabular}{|c|c|c|c|c|c|c|}
\hline \multirow[t]{2}{*}{ Blends } & \multirow[t]{2}{*}{ Code } & \multicolumn{5}{|c|}{ Means } \\
\hline & & Taste & Smell & $\begin{array}{c}\text { Crumb } \\
\text { Color }\end{array}$ & Texture & $\begin{array}{c}\text { Overall } \\
\text { acceptability }\end{array}$ \\
\hline $100 \%$ Rice & $\mathrm{r}$ & $2.3_{\mathrm{b}}$ & $2.1_{c}$ & $2.3_{\mathrm{c}}$ & $1.6_{\mathrm{c}}$ & $8.2_{\mathrm{d}}$ \\
\hline $100 \%$ Sorghum & $\mathrm{s}$ & $2.4_{\mathrm{b}}$ & $2.9_{\mathrm{ab}}$ & $2.0_{\mathrm{c}}$ & $2.8_{\mathrm{b}}$ & $10.0_{\mathrm{c}}$ \\
\hline $60 \%$ rice, $30 \%$ sorghum, $10 \%$ chic-pea 1 & $\mathrm{r} / \mathrm{s} / \mathrm{c}_{1}$ & $2.1_{\mathrm{b}}$ & $2.0_{\mathrm{c}}$ & $2.7_{\mathrm{b}}$ & $2.0_{\mathrm{bc}}$ & $8.7_{\mathrm{d}}$ \\
\hline $60 \%$ rice, $25 \%$ sorghum, $15 \%$ chic-pea 2 & $\mathrm{r} / \mathrm{s} / \mathrm{c}_{2}$ & $2.9_{\mathrm{b}}$ & $3.0_{\mathrm{a}}$ & $2.0_{\mathrm{c}}$ & $2.0_{\mathrm{bc}}$ & $10.0_{\mathrm{c}}$ \\
\hline $60 \%$ rice, $20 \%$ sorghum, $20 \%$ chic-pea 3 & $\mathrm{r} / \mathrm{s} / \mathrm{c}_{3}$ & $2.9_{\mathrm{ab}}$ & $3.0_{\mathrm{a}}$ & $3.0_{\mathrm{b}}$ & $2.4_{b}$ & $11.5_{\mathrm{b}}$ \\
\hline $60 \%$ rice, $30 \%$ sorghum, $10 \%$ chic-pea 4 & $\mathrm{r} / \mathrm{s} / \mathrm{c}_{4}$ & $3.1_{\mathrm{a}}$ & $3.0_{\mathrm{a}}$ & $3.0_{\mathrm{b}}$ & $3.0_{\mathrm{b}}$ & $12.1_{b}$ \\
\hline $60 \%$ rice, $25 \%$ sorghum, $15 \%$ chic-pea 5 & $\mathrm{r} / \mathrm{s} / \mathrm{c}_{5}$ & $4.0_{\mathrm{a}}$ & $3.1_{\mathrm{a}}$ & $3.1_{\mathrm{b}}$ & $4.0_{\mathrm{a}}$ & $14.2_{\mathrm{a}}$ \\
\hline $60 \%$ rice, $20 \%$ sorghum, $20 \%$ chic-pea 6 & $\mathrm{r} / \mathrm{s} / \mathrm{c}_{6}$ & $4.0_{\mathrm{a}}$ & $3.5_{\mathrm{a}}$ & $3.9 \mathrm{a}$ & $3.9 \mathrm{a}$ & $15.3_{\mathrm{a}}$ \\
\hline \multicolumn{7}{|l|}{ Standard check } \\
\hline $100 \%$ Australian wheat flour & $\mathrm{W}_{1}$ & 5.0 & 5.0 & 5.0 & 5.0 & 20.0 \\
\hline L.S.D. 0.01 & & 0.96 & 0.59 & 0.62 & 0.82 & 1.4 \\
\hline
\end{tabular}

The overall acceptability scores that combine all sensory evaluation attributes, cleared that, toast made from the two blends of $60 \%$ sorghum $+25 \%$ rice $+15 \%$ chic-pea and $60 \%$ sorghum $+20 \%$ rice + $20 \%$ chic-pea showed the highest overall acceptability by panelists (14.2 and 15.3/20, respectively). While, the second rank of overall acceptability was presented by blends of $60 \%$ sorghum $+30 \%$ rice $+10 \%$ chic-pea and $60 \%$ rice+ $20 \%$ sorghum $+20 \%$ chic-pea (12.1 and 11.5/15, respectively). The third rank of overall acceptability was that of $60 \%$ rice $+25 \%$ sorghum $+15 \%$ chicpea and $100 \%$ sorghum (10.0 and 10.0/15, respectively). The least overall accepted toast was that resulted from $60 \%$ rice $+30 \%$ sorghum $+10 \%$ chic-pea or $100 \%$ rice ( 8.7 and $8.2 / 20$, respectively).

To trace the contribution of blend elements on sensory evaluation characters, orthogonal comparisons between element's levels were made Table $1 r$. Raising the level of rice flour in blends from 305 to $60 \%$, gave a negative effect on toast panelist's sensory evaluation characters. That effect was significant for all traits. Meanwhile, blends with $60 \%$ sorghum flour, positively, surpassed those of $30 \%$ in all evaluation characters, with a significant contribution. Also, increasing chic-pea flour from 10 to $15 \%$, negatively affected all sensory evaluation elements, except for, toast crumb color. A further negative effect was resulted with increasing chic-pea flour from 15 to $20 \%$. The latter negative effect was not significant for toast texture.

Commonly, sensory evaluation of gluten-free toast was disliked in blends with $60 \%$ rice flour $v s$. those of $30 \%$ rice flour. While, blends with $60 \%$ sorghum flour, were most liked over those with $30 \%$ sorghum flour. Also, sensory evaluation of glutenfree toast was reduced as the contribution of chicpea flour to blend was ascending as 10,15 and $20 \%$.

Abdel-Kader (2000), scored a reduction of the diameter and weight of loaf as the amount of broad bean flour increased. The sensory properties of bread did not show any significant difference with 5 to $10 \%$ broad bean flour. Carson et al., (2000), found a higher score for sourness and astringency associated with sorghum flour. Olaoye et al., (2006) obtained insignificant difference in aroma, taste and general acceptability with mixing soy flour at 5\% level. Eissa et al., (2007), stated that, 15\% legume flour provided good sensory evaluation characters. Menom et al., (2012), reported that the addition of legume flour, improved sensory parameters (color and smell) of bread. Mohamed et al., (2012), postulated that, $20 \%$ chic-pea flour gave unacceptable bread to consumers. Minarro et al., (2012), showed that bread with legume flours showed an adequate sensory profile. They supposed chic-pea flour as promising legume flour. Phimolsiripol et al., (2012), recommended rice bran as a supplement to gluten free flour to increase dietary fiber and improve sensory evaluation. Wani et al., (2016), recorded a decrease in sensory evaluation characters (color, taste, aroma and overall acceptability) with blends had $15 \%$ or higher level of pulse flour.

\section{Toast shelf-life:}

Toast shelf-life was determined by a Texo-vol Texture analyzer (TVT) model 6700, Sweden. The objective was to quantitatively determine the force required to compress a baked toast by a preset distance. The firmness might be taken as a measure of freshness and quality. Measurements of TVT (peak force, and peak time) were taken in the first, second, third, fourth and fifth day.

Peak force $(\mathrm{g})$ required to shear toast with progress of storage from day one to day five were presented in Table $1 \varepsilon$. Overall storage days, toast made from $100 \%$ sorghum flour, showed the highest significant peak force $(5077 \mathrm{~g}$.). While, toast made from $100 \%$ rice flour came in the second rank with required peak force of 5013 (g.). 
Table 13: orthogonal comparisons between different levels of rice, sorghum and chic-peain free gluten blends on sensory evaluation characters of toast.

\begin{tabular}{lccccccccc}
\hline \multirow{2}{*}{ Comparison } & \multicolumn{4}{c}{ Effect } & \multicolumn{1}{c}{ Significant } \\
\cline { 2 - 9 } & Taste & Smell & $\begin{array}{c}\text { Crumb } \\
\text { color }\end{array}$ & texture & $\begin{array}{c}\text { Overall } \\
\text { acceptability }\end{array}$ & $\begin{array}{c}\text { Taste } \\
\text { Smell }\end{array}$ & $\begin{array}{c}\text { Crumb } \\
\text { color }\end{array}$ & $\begin{array}{c}\text { Overall } \\
\text { Texture }\end{array}$ \\
\hline acceptability
\end{tabular}


The third resistant toast was that resulted from $60 \%$ sorghum $+30 \%$ rice $+10 \%$ chic-pea flours $(4850$ g.). The fourth rank was shown by $60 \%$ rice $+30 \%$ sorghum $+10 \%$ chic-pea flour (4831 g.). A fifth rank was presented by any of $60 \%$ rice $+25 \%$ sorghum $+15 \%$ chic-pea flour or $60 \%$ sorghum + $25 \%$ rice $+15 \%$ chic-pea (4727 and 4737 (g.), respectively). The sixth peak force was required by $60 \%$ sorghum $+20 \%$ rice $+20 \%$ chic-pea (4649 g.) , While, the least value was that of $60 \%$ rice $+20 \%$ sorghum $+20 \%$ chic-pea (4623 g.). Overall blends, the required peak force was ascending with the progress of toast storage, with least value at day one (4944 g.) to maximum value $(4554 \mathrm{~g}$.) at day five. The least required peak force was that of toast made from $100 \%$ rice flour in day one (4300 g.), whereas, the highest peak force was recorded for toast made from any of $100 \%$ rice flour or $100 \%$ sorghum flour (5309 and 5309 (g.), respectively).
Commonly, stalling of toast expressed by peak force required to shear was ascending with the progress of storage. $100 \%$ rice toast expressed the least required peak force in day one and the maximum required peak force in fifth day. Overall storage days, the least stalled toast resulted from $60 \%$ rice $+20 \%$ sorghum $+20 \%$ chic-pea blend followed by $60 \%$ sorghum $+20 \%$ rice $+20 \%$ chicpea blend, then $60 \%$ sorghum $+25 \%$ rice $+15 \%$ chic-pea blend.

Maximum time (peak time) required to puncture or shear toast slice by TVT analyzer was presented in Table 15. Required peak time to shear toast slice was not different with progress of stalling days, overall studied free gluten blends. The highest peak time (sec.) was expressed by toast made from $100 \%$ rice flour $(3.24 \mathrm{sec}$.$) .$

Table 14: Peak force (g) of toast TVT shelf-life for the studied gluten-free blends as affected by days after baking.

\begin{tabular}{|c|c|c|c|c|c|c|c|}
\hline \multirow{2}{*}{ Blends } & \multirow{2}{*}{ Code } & \multicolumn{5}{|c|}{ Day } & \multirow{2}{*}{ Mean } \\
\hline & & 1 & 2 & 3 & 4 & 5 & \\
\hline $100 \%$ Rice & $\mathrm{r}$ & 4300 & 4988 & 5178 & 5288 & 5309 & $5013_{\mathrm{b}}$ \\
\hline $100 \%$ Sorghum & $\mathrm{s}$ & 4837 & 4953 & 4997 & 5288 & 5409 & $5077_{\mathrm{a}}$ \\
\hline $60 \%$ rice, $30 \%$ sorghum, $10 \%$ chic-pea 1 & $\mathrm{r} / \mathrm{s} / \mathrm{c}_{1}$ & 4331 & 4779 & 4906 & 5059 & 5078 & $4831_{\mathrm{d}}$ \\
\hline $60 \%$ rice, $25 \%$ sorghum, $15 \%$ chic-pea 2 & $\mathrm{r} / \mathrm{s} / \mathrm{c}_{2}$ & 4240 & 4681 & 4807 & 4945 & 4962 & $4727_{\mathrm{e}}$ \\
\hline $60 \%$ rice, $20 \%$ sorghum, $20 \%$ chic-pea 3 & $\mathrm{r} / \mathrm{s} / \mathrm{c}_{3}$ & 4147 & 4583 & 4707 & 4831 & 4847 & $4623_{\mathrm{g}}$ \\
\hline $60 \%$ rice, $30 \%$ sorghum, $10 \%$ chic-pea 4 & $\mathrm{r} / \mathrm{s} / \mathrm{c}_{4}$ & 4493 & 4768 & 4852 & 5059 & 5078 & $4850_{c}$ \\
\hline $60 \%$ rice, $25 \%$ sorghum, $15 \%$ chic-pea 5 & $\mathrm{r} / \mathrm{s} / \mathrm{c}_{5}$ & 4428 & 4668 & 4743 & 4878 & 4966 & $4737 \mathrm{e}$ \\
\hline $60 \%$ rice, $20 \%$ sorghum, $20 \%$ chic-pea 6 & $\mathrm{r} / \mathrm{s} / \mathrm{c}_{6}$ & 4362 & 4568 & 4633 & 4831 & 4847 & $4649_{\mathrm{f}}$ \\
\hline Mean & & $3944_{\mathrm{e}}$ & $4271_{d}$ & $4374_{c}$ & $4529_{b}$ & $4554_{a}$ & 4334 \\
\hline \multicolumn{8}{|l|}{ Standard check } \\
\hline $100 \%$ Australian wheat flour & $\mathrm{W}_{1}$ & 352 & 454 & 546 & 581 & 588 & 504 \\
\hline $\begin{array}{lr}\text { L.S.D. } 0.05 \text { blends } & 23.73 \\
\text { L.S.D. } 0.05 \text { days } & 17.69 \\
\text { L.S.D. } 0.05 \text { interaction53.07 } & \end{array}$ & & & & & & & \\
\hline
\end{tabular}

Table 15: Maximum time (peak time) required to puncture or shear toast slice by TVT analyzer.

\begin{tabular}{|c|c|c|c|c|c|c|c|}
\hline \multirow{2}{*}{ Blends } & \multirow{2}{*}{ Code } & \multicolumn{5}{|c|}{ Day } & \multirow{2}{*}{ Mean } \\
\hline & & 1 & 2 & 3 & 4 & 5 & \\
\hline $100 \%$ Rice & $\mathrm{r}$ & 2.97 & 3.30 & 3.30 & 3.30 & 3.30 & $3.24_{\mathrm{a}}$ \\
\hline $100 \%$ Sorghum & $\mathrm{s}$ & 1.96 & 1.96 & 1.96 & 1.96 & 1.96 & $1.96_{\mathrm{d}}$ \\
\hline $60 \%$ rice, $30 \%$ sorghum, $10 \%$ chic-pea 1 & $\mathrm{r} / \mathrm{s} / \mathrm{c}_{1}$ & 2.48 & 2.48 & 2.48 & 2.48 & 2.48 & $2.48_{b}$ \\
\hline $60 \%$ rice, $25 \%$ sorghum, $15 \%$ chic-pea 2 & $\mathrm{r} / \mathrm{s} / \mathrm{c}_{2}$ & 2.44 & 2.44 & 2.44 & 2.44 & 2.44 & $2.44_{b}$ \\
\hline $60 \%$ rice, $20 \%$ sorghum, $20 \%$ chic-pea 3 & $\mathrm{r} / \mathrm{s} / \mathrm{c}_{3}$ & 2.38 & 2.38 & 2.38 & 2.38 & 2.38 & $2.38_{\mathrm{b}}$ \\
\hline $60 \%$ rice, $30 \%$ sorghum, $10 \%$ chic-pea 4 & $\mathrm{r} / \mathrm{s} / \mathrm{c}_{4}$ & 2.17 & 2.17 & 2.17 & 2.17 & 2.17 & $2.17_{\mathrm{c}}$ \\
\hline $60 \%$ rice, $25 \%$ sorghum, $15 \%$ chic-pea 5 & $\mathrm{r} / \mathrm{s} / \mathrm{c}_{5}$ & 2.07 & 2.07 & 2.07 & 2.07 & 2.07 & $2.07_{\mathrm{c}}$ \\
\hline $60 \%$ rice, $20 \%$ sorghum, $20 \%$ chic-pea 6 & $\mathrm{r} / \mathrm{s} / \mathrm{c}_{6}$ & 1.97 & 1.97 & 1.97 & 1.97 & 1.97 & $1.97_{\mathrm{cd}}$ \\
\hline Mean & & 2.39 & 2.42 & 2.42 & 2.42 & 2.42 & 2.42 \\
\hline \multicolumn{8}{|l|}{ Standard check } \\
\hline $100 \%$ Australian wheat flour & $\mathrm{W}_{1}$ & 3.02 & 3.02 & 3.02 & 3.02 & 3.02 & 3.02 \\
\hline 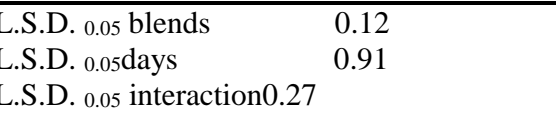 & & & & & & & \\
\hline
\end{tabular}


While, the second significant lower value of peak time was presented by toast made from any of $60 \%$ rice $+30 \%$ sorghum $+10 \%$ chic-pea, and $60 \%$ rice $+20 \%$ sorghum $+20 \%$ chic-pea blends $(2.48,2.44$ and $2.38 \mathrm{sec}$, respectively). Third lower rank of required peak time was expressed by any of $60 \%$ sorghum $+30 \%$ rice $+10 \%$ chic-pea, $60 \%$ sorghum $+25 \%$ rice $+15 \%$ chic-pea, $60 \%$ sorghum $+20 \%$ rice $+20 \%$ chic-pea $(2.17,2.07$ and 1.97 sec., respectively). The least required peak time was presented for $100 \%$ sorghum flour (1.96 sec.).

Commonly, it seems from the results that softness and cohesiveness of toast was maximized with $100 \%$ rice flour (high peak time), While, hardness, crispiness and friability were maximized with $100 \%$ sorghum flour (least peak time). High rice flour proportion gave intermediate characteristics of toast. Inclusion of rice flour with sorghum flour along with chic-pea flours increased toast hardness; consequently, reduced peak time required for shearing or punctures.

According to Baik and Chinachoti (2003) the stalling process can lead to a hard and crumbly texture and a loss of Freshbaked Flavor. Gambaro, et al., (2004) demonstrated that, the stalling of pan bread caused a change in appearance (color, visual dryness), odor and several texture characteristics (smoothness, softness, hardness and cohesiveness). DijKsterhuis, et al., (2007) showed an increase in hardness and decrease in crispiness and friability in bread model products over time.

Stalling is used to describe a group of mechanisms which have in common that they make the product texture and flavor unacceptable over time. The most notable result in bread is that it becomes firmer as they age, less elastic and having off-flavor. The stalling can be measured subjectively through sensory test, or by measuring the force required by an instrument puncturing the bread. A mechanism that contributes to stalling includes starch retrogradation and moisture migration. Cauvain and Young, (2006), explained starch retrogradation. They stated that the heating of starch rich products, such as bread, causes starch granules to absorb water and swell. This reduces the starch crystalline and causes a gel like matrix with a higher viscosity due to hydrogen bonds between the starch and water. This starts to change as soon as the product leaves the oven as recrystallization of the starch into a differently ordered structure, starts immediately when the product begins to cool. This recrystallization is what is referred to as starch retrogradation. Stalling that has found to occur most rapidly, the first hours after baking is due to recrystallization of unbranched amylase chains. The stalling that takes place during the majority of storage is instead due to the slower recrystallizing branched, amylopectin chains. Factors that affect the rate of starch retrogradation includes, time and the composition of product, especially, the type and amount of sugars, lipids, peptides, and water content. The recent results might be discussed depending on the available literature. Sidhu et al., (1997), cleared that, the amount of soluble starch and amylose contents were decreased significantly as bread aged during storage. Gary and Bemiller (2003), supported the hypothesis provided by Cauvian and Young (2006), illustrating that retrogradation of amylopectin occurs, and because water molecules are incorporated into the crystallites, the distribution of water is shifted from gluten to starch, amylopectin, thereby changing the nature of the gluten network. Eissa et al., (2007) reached that addition of fenugreek flour to blend improved stalling characters of the bread. Sciarini et al., (2010), concluded that, xanthan gum introduction to $100 \%$ rice flour, lowered the stalling rate over storage. Phimolsiripol et al., (2012), extended shelf-life of gluten free bread, by adding rice brane to flours blend. Fada et al., (2014), confirmed the central role of amylopectin retrogradation and water redistribution within the different polymers in determining bread staling. Thushan Sanjeewa et al., (2012), illustrated the role of legume flour addition in late stalling of bread as too water holding capacity of legume flour.

\section{REFERENCES}

AACC- 10-05.01. 1999. American Association of cereal chemists. Baking volume method.

AACC- 10 - 90.01. 2000. American Association of cereal chemists. Cake making method.

AACC-14 -22.01. 1999. American Association of cereal chemists. Color properties method.

AACC-22 -10.01. 1999. American Association of cereal chemists. $\mathrm{X}$ - amy lase activity method.

AACC- 30 - 10.01. 1999. American Association of cereal chemists. Crude fat in flour, Bread, and baked cereal products, method.

AACC- 33-50.02. 2000. American Association of cereal chemists. Sensory evaluation method.

AACC- 38-12.02. 2000. American Association of cereal chemists. Gluten content method.

AACC- 54 - 10.01. 1999. American Association of cereal chemists. Extensigraph records method.

AACC-54- 21.01. 1999. American Association of cereal chemists. Farinograph measures method.

AACC- 54 -30.02. 1999. American Association of cereal chemists. Alveograph measures method.

AACC-56 - 81.03. 1999. American Association of cereal chemists. Falling number.

AACC- 66 - 41.01. 2000. American Association of cereal chemists. Pasta quality method.

AACC- 66 - 50.01. 2000. American Association of cereal chemists. Pasta cooking characteristics method. 
AACC- 74-09. 01. 2000. American Association of cereal chemists. TVT (shelf-life) analyzer method.

AACC-32 - 10. 01. 1999. American Association of cereal chemists. Crude fiber method.

AACC-44 - 19. 01.1999. American Association of cereal chemists. Moisture - Air - oven method.

AACC-46 -11.02. 1999. American Association of cereal chemists. Crude protein method.

AACC-76 - 33.01. 1999. American Association of cereal chemists. Damaged starch method.

Abdel-Kader, Z.M. 2000. Enrichment of Egyptian 'Balady' bread. Part 1. Baking studies, physical and sensory evaluation of enrichment with decorticated cracked broad beans flour (Vicia faba, L.). Nahrung 44 (6): 418-421.

Arendt, E. K., A. Morrissey, M. M. Moore, and F. Dal Bello. 2008. Gluten-free bread. Gluten free cereal products and Beverages, strany 289 319.

Arendt, E. K., A. S. Hager, and C. Axel. 2011. Statusofcarbohydratesanddietaryfiberinglutenfreediets. CerealFoodWorld, 6;109-114.

Arendt, E., C. O. Brien, T. Schober,. 2002. "Development of gluten-free cereal products. Farm and Food: 21-27.

Baik,M.Y., and P. Chinachoti. 2003. Water diffusion coefficient and stalling of white bread as affected by glycerol. Cereal Chem., 80(6):740744.

Berti., C., P. Riso, L. D. Monti. 2004. "In vitro starch digestibilityand in Vivo glucose response of gluten-free foods and their gluten counterparts." European Journal of Nutrition, 43 (4); 198- 204.

Bhatt, S.M. and R.K. Gupta. 2015. Bread (composite flour) formulation and study of its nutritive, phytochemical and functional properties. Journal of Pharmacognosy and Phytochemistry, 4(2): 254-268.

Butt, M.S., J. Iqbal, A. Naz, H.A.R. Suleria1, M.M.N. Qayyum, Faiza Saleem and M.A. Jahangir. 2011. Effect of Flour Blending on Bread Characteristics. Internet Journal of Food Safety, 13: 142-149.

Cauvian, S. P. and L. S. Young. 2006. Baked products: science, Technology and Practice. Blackwell publishing LTD, 9600 Garsington Road, oxford, ox4 2Dq. Uk.

Cochran, W.C. and G.M Cox (1957). Experimental design. $2^{\text {nd }}$ ed., Johan Willey and Sons, New York, USA.

Demirkesen, I.B. Mert, G. Sumnu, and S. Sahin. 2010.

Rheologicalpropertiesofglutenfreebreadformul ations. J. Food Eng., 96; 295-303.
Dijksterhuis,G.,H. Luyten, R.De.Wijk, and J.Mojet. 2007. A new sensory vocabulary for crisp and crunchy dry model food. Food Quality and Preference, 18 (1): 37-50.

Eissa, H.A., A.S. Hussein and B.E. Mostafa. 2007. Rheological properties and quality evaluation of Egyptian balady bread and biscuits supplemented with flours of ungerminated and germinated legume seeds or mushroom. Polish Journal of Food and Nutrition Science, 57 (4): 487-496.

Fadda, C., A.M. Sanguinetti, A.Del Caro, C. Collar and A. Piga. 2014. Bread Staling: Updating the View. Comprehensive Reviews in Food Science and Food Safety, 13: 473- 492.

Gambaro, A., S. Fiszman, A. Gimenez, and A. Salvador. 2004. Consumer acceptability compared with sensory and instrumental measures of white pan bread; sensory shelf-life estimation by survival analysis. Journal of food science 69(9),: 401-405 .

Gallagher, E., T. R. Gormley, and E. K. Arendt. 2004. Recent advances in the formulations of gluten free cereal based products. Trends in Food Science and Technology, 15: 143-152.

Gómez M., B.Oliete, C. M.Rosell, V. Pando, and E. Fernández. 2008. Studies on cake quality made of wheat- chickpea flour blends. LWT Food Sci. Technol., 41: 1701-1709.

Green, P. H. R. and C. Cellier. 2007. Medical progress: Celia disease. New England Journal of Medicine, 357 (17); 1731-1743.

Hagar, A. -S., A. Wolter, M. Czerny. 2012. Investigation of product quality, sensory profile and ultrastructure of breads made from a range of commercial gluten-free flours compared to their wheat counterparts. European Food Research and Technology, 235 (2); 333 - 344.

Hager A., L. Ryan, C. Schwab, M.Ganzle, J.O'Doherty, and E. Arendt .2011. Influence of the soluble fibres inulin and oat beta-glucan on quality of dough and bread. Eur. Food Res. Technol. 232; 405-413.

Hager, A.; A. Wolter, M. Czerny, J. Bez, E.Zannini, and E. Arendt .2013. Investigation of product quality, sensoryprofile and ultrastructure of breads made from a range of commercial gluten-free flours compared to theirwheatcounterparts.Eur.FoodRes.Technol,2 35; 333-344.

Harinder, K., B. Kaur and S. Sharma .1999. Studies on the baking properties of wheat: Pigeonpea flour blends. Plant Foods for Human Nutrition, 54: 217-226.

Hemeda, H. M., and E. F. Mohamed. 2012 Functional attribute of chickpea and defatted soybean flour blends on quality characteristics of shortening cake. European Journal of Applied Sciences, 2: 44-50. 
Hooda, S. and S. Jood. 2005. Effect of fenugreek flour blending on physical, organoleptic and chemical characteristics of wheat bread. Nutrition and Food Science, 35 (4): 229-242.

Islam, M.Z., M. Shams-Ud-Din and M.A. Haque. 2011. Studies on the effect of brown rice and maize flour on the quality of bread. Bangladesh Agril. Univ. 9(2): 297-304.

Kadam, M. L., R. V. Salve, Z. M. Mehrajfatema, and S.G. More. 2012. Development and evaluation of composite flour for Missi roti/chapatti. Food Process and Technology, 3, 1000134. DOI: 10.4172/2157-7110.1000134.

Lalit, H. and A. Kochhar. 2017. Development and organoleptic evaluation of bread formulated by using wheat flour, barley flour and germinated. Chem. Sci. Rev. Lett., 6(23): 1728-1734.

Lazaridou, A., D. Duta, M.Papageorgiou, N.Belc, and C.G. Biliaderis. 2007. Effects of hydrocolloids on doughrheology and bread quality parameters in gluten-free formulations.J. Food Eng., 79; 1033-1047.

Livingstone A. S., J. J. Feng, and N. G. Malleshi. 1993. Development and nutritional quality evaluation of weaning foods based on malted, popped and dried wheat and chickpea. Inter. J. Food Sci. Technol., 28: 35-43.

Maninder, K., K. S. Sandhu, and N. Singh .2007. Comparative study of the functional, thermal and pasting properties of flours from different field pea (Pisum sativum L.) and pigeon pea (Cajanus cajan L.) cultivars. Food Chemistry, 104: 259 - 267.

Mastromatteo, M., A. Danza, M. Guida, and M. A. DelNobile. 2012. Formulation optimization of vegetable flour-loaded function albread Part I: Screen in gofvegetable flours and structuring agents. Int. J. FoodSci.Technol.,47;1313-1320.

Miñarro, B., E. Albanell, N. Aguilar, B. Guamis and M. Capellas. 2012. Effect of legume flours on baking characteristics of gluten-free bread. Journal of Cereal Science, 56: 476- 481.

Mohammed, I., A. R. Ahmed, B. and Senge. 2012. Dough rheology and bread quality of wheatchickpea flour blends. In- dustrial Crops and Products, 36, 196-202. DOI: 10.1016/j. indcrop. 2011.09.006.

Mohammed, I., A.R. Ahmed, B. Senge. 2012. Dough rheology and bread quality of wheatchickpea flour blends. Industrial Crops and Products, 36: 196 -202.

Olaoye, O.A., A.A. Onilude and O.A. Idowu. 2006. Quality characteristics of bread produced from composite flours of wheat, plantain and soybeans. African Journal of Biotechnology, 5(11): 1102-1106.
Perez-Hidalgo M.A., E. Guerra-Hernandez, and B. Garcia-Villanova. 1997. Dietary fiber in three raw legumes and processing effect on chick peas by an enzymatic-gravimetric method. J. Food Compost. Anal., 10: 66-72.

Phimolsiripol, Y., A. Mukprasirt and R. Schoenlechner. 2012. Quality improvement of rice-based gluten-free bread using different dietary fibre fractions of rice bran. Journal of Cereal Science, 56: 389-395.

Rai, S., A. B. Kaur, K.S. Singh and Minhas. 2012. Quality characteristics of bread produced from wheat, rice and maize flours. Food Sci. Technology, 49(6): 786-789.

Renzetti, S., B.F. Dal and E. Arendt. 2008. Microstructure, fundamental gluten-free flours treated with a microbial transglutaminase. Journal of Cereal Science, 48; 33-45.

Renzetti, S., C. M. Courtin, J. A. Delcour. 2010. Oxidative and proteolytic enzyme preparations as promising improvers for oat bread formulations: Rheological, biochemical and microstructural background. Food Chemistry, 119 (4); 1465-1473.

Roberts, K.T., S.W. Cui, Y.H. Chang, P.K.W. Ng and T. Graham. 2012. The influence of fenugreek gum and extrusion modified fenugreek gum on bread. Food Hydrocolloids, 26; 350- 358.

Rysová, J., J. Ouhrabková, D. Gabrovská, I. Paulíčková, R. Win- terová, T. Vymyslický, J. Prokeš, and M. Hutař. 2010. Food with addition of little-known legume varieties. Agronomy Research, 8: 339 -344.

Sadowska, J., W. B-laszczak, J. Fornnal, C. VidalValverde, and J. Frias .2003. Changes of wheat dough and bread quality and structure as a result of germinated pea flour addition. European Food Research and Technology, 216, 46-50. DOI: 10.1007/s00217-002-06178.7-9 7-2.

Schober, T. J., M. Messerschmidt, S. R. Bean. 2005. Gluten-free bread from sorghum: Quality differences among hybrids. Cereal Chemistry, 82 (4); 394-404.

Sciarini, S.L., D.P.Ribotta, E.A. Leon, and T.G. Perez. 2010. Influence of gluten-free flours and their mixtures on batter properties and bread quality.FoodBioprocessTechnol.,3; 773780 .

Sidhu, J.S., J.Al-Saqer and S. Al-Zenki. 1997. Comparison of methods for the assessment of the extent of staling in bread. Food Chemistry, 58(1-2): 161-167.

Sotomayor C., J. Frias, J. Fornal, J. Sadowska, G. Urbano, and C. Vidal-Valverde .1999. Lentil starch content and its microscopical structure as influenced by natural fermentation. StarchStarke, 51(5):152-156. 
Tanaka, Y. 1972. Quality Improvement of Rice Bread. Jarq J., 6(3): 181-187.

Thushan Sanjeewa, W. T., J. P. D. Wanasundara, Z. Pietrasik, and P. J. Shand. 2012. Characterisation of chickpea (Cicer arietinum L.) flours and application in low-fat pork bologna as a model system. Food Research International, 43:617-626.
Wang, N., P. R. Bherud, F.W. Sosulski, and R. T. Tyler. 1999. Pasta like product from pea flour by twin-screw extrusion. Journal of Food Science, 64: 671-678.

Year book of Agricultural statistics. 2018. Ministry of Agriculture and land reclamation, Egypt.

Zlatica, Kohajdová, J. Karovicova, and M. Jurasova. 2012. Influence of carrot pomace powder on the rheological characteristics of wheat flour dough and on rolls quality. Act. Sci. Pol.,Technol.Aliment., 11(4): 381-387.

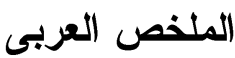

\section{مستقبل استخدام الحبوب والبقول المحليه لاتتاج خبز توست خالى من الجلوتين فى مصر

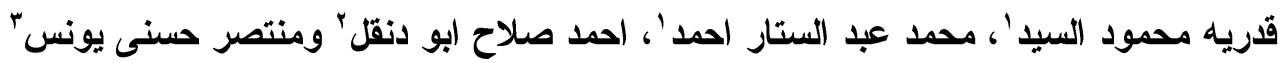

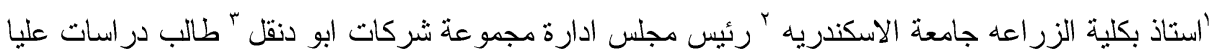

الهدف الرئيسى للار اسه الحاليه هو انتاج خبز توست خالى من الجلوتين باستخدام حبوب وبقول محليه الانتـــاج فى مصر ويمثلها الارز و الذره الرفيعه و الحمص. نم الحصول على حبوب الارز الكسر والذره الرفيعه و الحمــص من السوق المحليه. ونفذت التجارب فى معامل الثركه العربيه للمطاحن و الصناعات الغذائبه (احدى شركات صلاح ابو دنقل). استخدمت ستة خلطات من المكونات السابقه بالاضافه الى الدقيق المنفرد لكل من دقيق الارز ودقيق الذره الرفيعه. تضمنت الدر اسه صنفان من القمح كعينه قياسيه للمقارنه. المستويات المرتفعه من دقيق الذره الرفيعه فـى

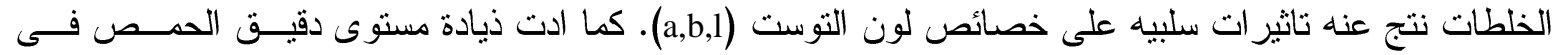
الخلطات من 10 الى ·r \% الى ناثيرات سلبيه على درجة اللون الابيض و اللون الاصفر للتوست مع تحسـن فـى

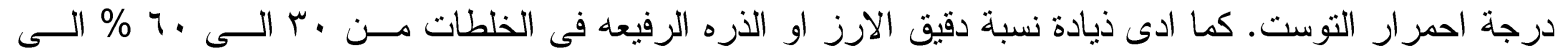

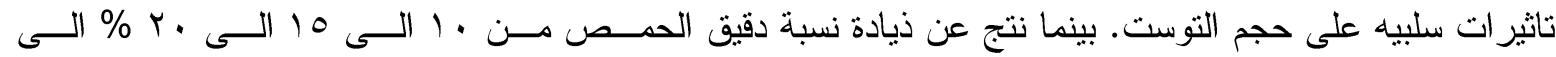
تاثير اتايجلبيه على حجم التوست. وعموما فالتوست الناتج من دقيق الارز بمفرده، احتوى على اقل نسبه من الالياف الخام. ومع تذايد نسبة دقيق الحمص فى مخاليط دقيق الذره الرفيعهو الارز انخفضت درجة تفضيل التوست النـاتج

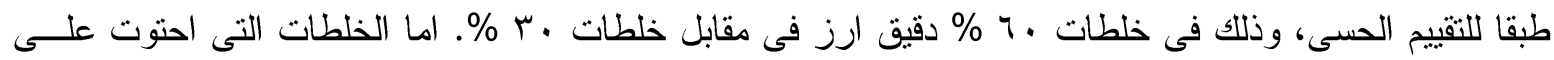
• ؟ \% دقيق ذره رفيعه فقد حازت على القبول من حيث التقييم الحسى مقارنة بالخلطات المحتويه على ، 7 \% دقيق

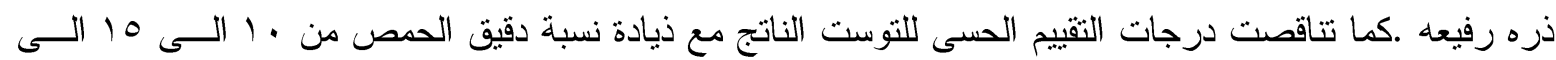

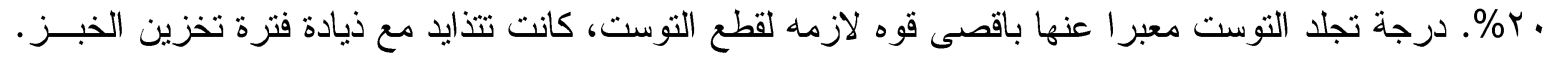

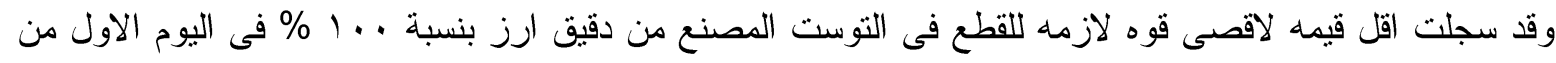

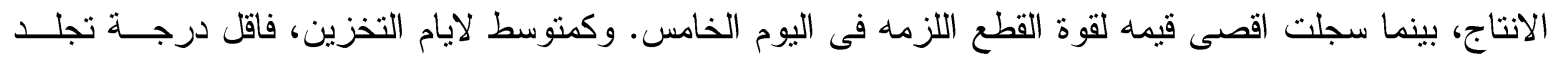

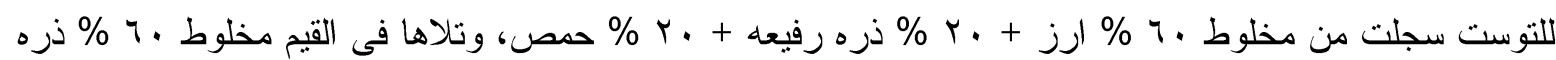

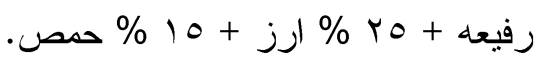

